these various library services, and bibliographic instruction has been a challenge. During the academic year, orientations and workshops are held at site offices around the state to explain the College's library system. Specific courses in research and writing are listed in the college catalog and arranged for students. Staff development days are held on a yearly basis. Site coordinators work with instructors to incorporate research objectives into course descriptions and plan formal library instruction periods for students each semester. BI remains the largest goal in the library planning, and the staff continues to experiment with ways of providing information electronically without sacrificing the value of close human interaction and the serendipity of traditional library browsing.

Until three years ago there was very little resource sharing among the Vermont State Colleges libraries. Interlibrary loan was available from the Vermont Department of Libraries and most often took from two to three weeks for delivery of books. Times have changed dramatically, and 1987 finds all five of the state colleges working together on the tasks of collection development, a joint serials list, increased use of online searching, retrospective conversion, a joint online catalog, and a common policy for online searches.

When the Governor cut the computer ribbon in December, many librarians' hearts beat just a little bit faster knowing that the plunge in to the world of "electronic libraries" was imminent. For Cormmunity College of Vermont, it means that for the first time in its history, students will be able to access the online catalog from any site office, and then receive materials directly. It is expected that this phase of the library project will be available to CCV students by fall 1987. The truth of the matter is that the College could not have come this far without a little help from its friends.

\title{
ALA candidates on ACRL
}

\author{
The three candidates for $A L A$ \\ vice-president/president-elect share their views on \\ academic and research librarianship.
}

\section{$\mathbf{R}$} Hecentry the ALA presidential candidates were asked to give some thought to ALA/ACRL relations and academic librarianship in general for this special $C \& R L$ Netws feature. Their statements may aid you when you vote for ALA officers on this spring's ballot.

\section{Linda Anne Dougherty:}

My recollection of academic libraries is very much based on my school days at Indiana University where I worked in both the Undergraduate Library and in the Law Library. Point of service librarians who have been active in the AI, A I, ibrary Instruction Round Table have told me of their con- cerns for the future of academic libraries.

The mission of academic libraries can be no different from that of any library-we all must serve our communities, providing the greatest access to all. I value "halls of residence libraries," and I believe that undergraduate collections and staff can provide a special teaching resource to the "entry level" college student. These ideas relate to my contention that a librarian's involvement with lifelong learning ties us into a continuum of learning. Those of us interested in user education know that the academics have clearly led the way in this discipline. We do have to question, however, if we wait to educate only the college-bound how elitist and narrow our instruction has become. Within academic 
libraries a major concern has been the decline in enrollment. The resulting budget crisis is a familiar problem. The growing interest in adult education programs shows how many campuses have sought to reach out to a new market for another type of student population.

The definition of "town and gown" must be redefined to "campus." And the idea of campus needs to be as broad and inclusive as possible. The mission of academic libraries is to reach out. Last year Charles W. Robinson wrote that "the greatest proportion of library users are children and students." In the public library sector we know of the massive shortages of trained children's librarians; we also know that in some instances school librarians are not valued as co-cducators, but have a half-life in their institutions. Should we be surprised then when one tax levy after another fails; when youth question the value of a liberal arts education; and when campus after campus declines and closes?

These realities aren't cited to make us full of despair. They are montioned becuase our mission - to provide service-must be undertaken with enthusiasm and a little bit of the zealot's fervor. If we are not aggressive in our presentation of self, who will battle for us?

Again, I think my colleagues in bibliographic instruction have provided the model. They reached out to departments; reached out to students; they united "instruction" with "subject content."

So my notion of the mission of academic libraries involves some of that old idea of "outreach," I speak to many audiences where I say, "How many of you can name your doctor, your baker, your butcher, your auto mechanic? Now how many of you can name any member of your library's staff?" ... You can see how extensive my notion of our mission is. ACRL has a definite role to play-it is

\section{Let's do lunch}

The ALA Library Instruction Round Table is providing an opportunity for BI librarians to talk informally with others interested in library instruction at Annual Conference in San Francisco. Because it is so difficult to meet librarians with similar interests at large conferences, I.IRT is organizing small groups for lunch or dinner at modestly priced restaurants. The Library Instruction Round Table is made up of librarians from all types of libraries: academic, public, school, and special. You need not be a member to participate.

Send your name, institution, and mailing address by May 20 to Deborah I. Schaeffer, Reference, Renne Library, Montana State University, Bozeman, MT 58717. Indicate your two preferences for the following time slots: Lunch at 12:30 on Saturday, June 27, Sunday, June 28, or Monday, June 29; dinner at 6:30 on Sunday, June 28, or Monday, June 29. the biggest and richest division of ALA. Now it has the challenge of reaching its mission of service.Linda Anne Dougherty, Clearing Branch, Chicago Public Library, 5643 W. 63rd St, Chicago, Illinois.

\section{Kenneth E. Dowlin:}

I am confident that my program for ALA is supportive to the interests of college and research libraries.

While my career has been totally in public libraries, I believe that protecting, and increasing, access to information and knowledge is critical in all areas of this democratic society; and that in support of that belief, ALA should dcvelop a strategy to develop a national policy on access to information and knowledge in communities, and should

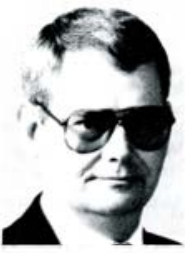

Kenneth E. Dowlin promote and monitor the development of technological standards for data interchange.

I believe that an active image of libraries in our institutions and communities needs to be projected, rather than the passive image held by many people. In order to accomplish this goal, ALA must articulate the shared values inherent in librarianship, should reassess its policy on the education of librarians and other library employees, and should create an aggressive communication program to promote the shared values to our institutions and communities.

In order to provide leadership in access to information and knowledge, ALA must be an active, relevant organization. I support the strategic planning process that is now in place. I support research and development in their efforts to communicate to the public, and I strongly support linking libraries throughout the world in an effort to create a living window-of-the-world for our users.

College and research libraries are the touchstones of their institutions. ALA must provide support through technical standards for data interchange, ensuring quality educational programs, and leadership to the field. The world around us is one of rapid change, requiring us to share our strengths to better cope with the challenges of the future.-Kenneth E. Doulin, Director, Pikes Peak Library District, Colorado Springs, Colorado.

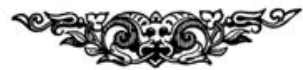




\section{F. William Summers:}

ACRL is in many ways the prototypical ALA division. It shows great strength in its programs, in its membership and in its publications. ACRL is fiscally the most healthy of the ALA divisions and is the model other divisions look to in hoping for a brighter future. Its accomplishments are truly impressive with a large membership and a healthy financial balance. Certainly as a membership unit of ALA it is strong. But all libraries (except a handful of autonomous institutions) are in the final

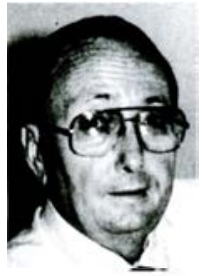

F. William Summers analysis dependent for their health upon the basic condition of the parent institution of which they are a part. Quite clearly the American academic institution is today showing signs of great stress and the academic library along with it.

The sources of stress are manifold and are recited with depressing regularity in publication after publication-the decline in the student cohort; rising costs of staff, and for libraries of materials; a decline in public confidence and with it greater recalcitrance of funding bodies to increase basic support. The list could be added to almost infinitely. In addition the academic library faces additional serious challenges.

Not many years ago the academic library held a virtual monopoly on the distribution of information on campuses. Its only near rival was the campus bookstore which often devoted greater energy to the sale of trinkets and souvenirs than to information distribution. Today on campus after campus that is not the case. The academic library competes for scarce resources with a great many other information providers. Among them are an instructional media support program, a campus radio-TV complex, and, the most potent and expensive resource, a campus computer facility. All of these facilities compete for relatively static, and in some cases declining, resources.

At the same time the academic library faces great challenges in paying for its own technological development. Academic libraries have made an enormous commitment to technology with bibliographic networks, online catalogs, and new ways of delivering information. Because of these forces academic libraries have been leading the way in the profession in calling for better training for library staffs, continuing education for existing staffs to make them more productive and effective, and serious efforts at containing the rapidly escalating costs of library materials. What can I do about these problems as AI A president?

First, the ALA president can give visibility and impetus to the issues facing the profession. The privatization of NTIS, the declines in government publishing, and the switch of publications from government to private publication will place further great stress on already strained academic library budgets.

Second, the ALA president can make committee appointments of people with proven records in devising hard and innovative solutions to difficult problems and can pose agendas for those committees which deal directly and forthrightly with the major issues confronting libraries.

Third, and perhaps most importantly, the ALA president can use the platform of the presidency to speak out on the issues concerning our academic and other types of libraries in appearances before Congress, in the press, and in international forums of the profession.

Our problems with copyright; with diminishing and vanishing government information; with differential pricing from foreign and domestic publishers; with recruiting and properly training the staffs needed for modern academic libraries and with overwhelming cost increases for technology and telecommunications will not be resolved within the term of any single ALA president, but I pledge the members of ACRL and, indeed of all ALA divisions, to strengthen ALA's efforts at solving them, to address them in an articulate and responsible manner, and to appoint the best colleagues I can identify to continue to address them. My professional record, which will appear in a number of journals and on the ballot, will demonstrate a record of sustained professional leadership and accomplishment, and I earnestly solicit your vote in the ALA election. - F. William Summers, Dean, School of Library and Information Studies, Florida State University, Tallahassee.

\section{CLIP query}

The CLIP Notes Committee of the College Libraries Section is updating the list of libraries surveyed for the collections of documents published through the CLIP Notes series. Library directors at liberal arts colleges and comprehensive colleges and universities (according to the Carnegie classification) who have documentation for future CLIP Notes publications are encouraged to submit their name for inclusion on the updated list. Please write to: Larry Hardesty, Director of Library Services, Eckerd College Library, St. Petersburg, FL 33712.

Future surveys are planned in the areas of position descriptions, annual reports, friends of the library, and collection development. Participation by libraries with well-written documents results in highly useful CLIP Notes. 